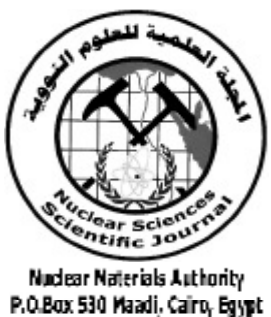

ISSN 2314-5609

Nuclear Sciences Scientific Journal

$7,73-85$

2018

http://www.ssnma.com

\title{
NATURAL RADIOACTIVITY, MINERALOGY AND RADIOLOGICAL HAZARD ASSESSMENT OF FELDSPARS FROM ESH EL MELAHA RANGE, EASTERN DESERT, EGYPT
}

\author{
AMR A. ABDEL HAMID and HASSAN I. EL SUNDOLY \\ Nuclear Materials Authority, P.O. 530 El-Maadi, Kattamyia, Egypt
}

\begin{abstract}
The feldspars at Esh El Melaha range, North Eastern Desert of Egypt, are excavated from Gabal Homret Al Gerigab and Gabal Esh areas. They are separated from the stream sediments, which characterized by granitic composition and contain high amounts of feldspar phenocrysts. The two feldspar occurrences were sampled from their quarry stockpiles and the activity concentrations of $U, T h, R a$ and $\mathrm{K}$ were determined by gamma ray spectrometry. The abundance of these radionuclides in Gabal Homret Al Gerigab are higher than those in Gabal Esh area, except $\mathrm{K}$ that is higher in all feldspar samples. However, for all feldspar samples, the radiometrical measurements are higher the recommended levels of these radionuclides.

The mineralogical characterizations of the investigated feldspars indicated that zircon, monazite and to a lesser extent fluorite are the main radioactive accessory minerals. The contents of these minerals in a given sample were affecting directly on the level of radioactivity. The elevated concentrations of natural radionuclides in Gabal Homret Al Gerigab area are connected with the presence of higher quantities of the aforementioned accessory minerals.

In order to assess the radiological impact from the investigated feldspars, parameters such as radium equivalent activities, external hazard index and absorbed dose rate were determined. The results indicated that the use of the studied feldspars as raw materials for ceramic industry is unsafe to the public due to their elevated radioactivity. The studied feldspars require intensive purification from the radioactive accessory minerals by the application of suitable technologies of magnetic separation and chemical processing.
\end{abstract}

\section{INTRODUCTION}

The demand for feldspars as raw materials for the ceramic industries is continuously increasing. In Egypt,most of the commercial feldspars are excavated from stream sediments, which originated in source areas of granitic rocks high in feldspar phenocrysts. The most important of them are located in the Eastern Desert, whereas numerous granitic plutons are cropout.

The natural radioactivity of feldspars used as ceramic raw materials, located in the Eastern
Desert of Egypt,was studied by other authors. Walley El-Dine et al. (2011) determine the natural radioactivity and rare earth elements in feldspar samples from pegmatite bodies of Abu Dob area. They concluded that the level of radioactivity of feldspar samples are higher than the permissible levels that cause a great effect on the health of humans, especially those working in the area. Aboelkhair et al. (2012) studied the gamma activity of stream sediments feldspars of Gabal El Missikat and Gabal Homret Al Gerigab areas and their environmental impact. They stated that the natural 
radioactivity levels in the two areas lie within the international recommended limits for occupational feldspar quarry workers but may yield an undesired impact on the environment, especially through the indoor applications.

The present study focused on two feldspar occurrences located at Esh El Melaha range, North Eastern Desert of Egypt, in Gabal Homret Al Gerigab and Gabal Esh areas.This study aims to detect the natural radioactivity of the feldspars used as ceramic raw materials in perspective to the mineralogical compositions. We also carried out an assessment of the radiological hazards based on activates of studied feldspars.

\section{GEOLOGICAL SETTING}

Esh El Melaha range is located in the North Eastern Desert of Egypt. It forms a conspicuous segment of the Red Sea Hills running in a roughly NW-SE direction parallel to the Gulf of Suez (Fig. 1a). The feldspars,at Esh El Melaha range, are quarried from stream sediments of Gabal Homret Al Gerigab and Gabal Esh areas. They are formed due to the accumulation of the liberated clastics produced by weathering from the surrounding granitic rocks. They are of Quaternary age and include clays, sands, pebbles and boulders. The source granitic rocks are leucocratic and contain frequent amount of K-feldspars. The granites of Gabal Homret Al Gerigab and Gabal Esh areas are classified as alkali feldspar granite and syenogranite, respectively according to their chemical compositions (Abdel Hadi, 2013, Esmail and Tawfik, 2015). They are belonging to the younger group of granitic rocks in Egypt, which have ages ranges from 568 to 597Ma (Fullagar and Greenberg, 1978; Hashad, 1980) and may extending to 622Ma (Meneisy and Lenz, 1982) or even to $641 \mathrm{Ma}$ (Moussa, 1998).

Gabal Homret Al Gerigab area is delineated by Lat. $27^{\circ} 44^{\prime}-27^{\circ} 48^{\prime} \mathrm{N}$, and Long. $33^{\circ}$ $17^{\prime}-33^{\circ} 22^{\prime} 30^{\prime \prime} \mathrm{E}$. The study area is mainly occupied by the Pan-African basement rocks. It is mainly covered by Dokhan volcanics and alkali feldspar granite with some dyke swarms as well as Quaternary sediments (Fig. 1a). The feldspar quarry occurs in Khalig Abu $\mathrm{Had}$ at the western margins of Gabal Homret Al Gerigab (Fig. 2a). The feldspars are found in the dry wadis and separated from the stream sediments by sieving between sizes of 1.0 and $0.5 \mathrm{Cm}$ then cumulated as stockpiles. The source rock of the feldspars is the alkali feldspar granite, which is well represented by Gabal Homret Al Gerigab pluton at the central part of the mapped area, covering an area of about $10 \mathrm{~km}^{2}$. This granite is medium to coarse grained,hard and blocky of red to reddish pink color. It mainly consists of $\mathrm{k}$-feldspar and quartz as essentially minerals with subordinate plagioclase and displays hypidiomorphic equigranular texture. The mafic minerals are scarce giving rise to the leucogranite type.

Gabal Esh area is bounded by lat. $27^{\circ} 25^{\prime}$ $27^{\circ} 35^{\prime} \mathrm{N}$ and long. $33^{\circ} 30^{\prime}-33^{\circ} 35^{\prime} \mathrm{E}$. It is mainly covered by Dokhan volcanics and syenogranite with associated dikes and veins as well as the Miocene and Quaternary sediments (Fig. 1c). The Quaternary stream sediments are filling the wadis and constitute colluvial cover on the mountainous terrains. The quarrying of feldspars is present at the eastern peripheries of Gabal Esh granite, which constitutes the source rocks of these feldspars (Fig. 2b). The investigated feldspars are sieved from the stream sediments between sizes of 1.0 and $0.5 \mathrm{~cm}$, which collected as stockpiles. Gabal Esh syenogranite is medium-grained, light pink, hard and massive rocks. It is characterized by the deficiency of ferromagnesian minerals, giving rise to a leucocratic type. It is essentially composed of k-feldspar and quartz with subordinate amount of plagioclase as well as accessory minerals.

\section{MATERIALS AND METHODS}

\section{Sampling and Sample Preparation}

The quarry occurrences of the studied areas contain numerous feldspar stockpiles. A total of 35 representative samples have been 
(a)

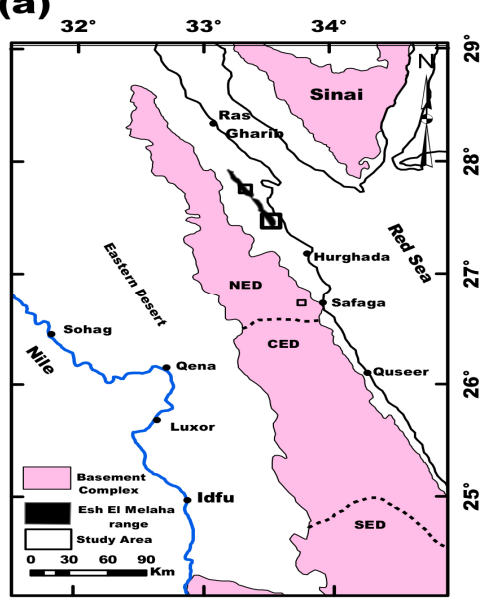

(c)

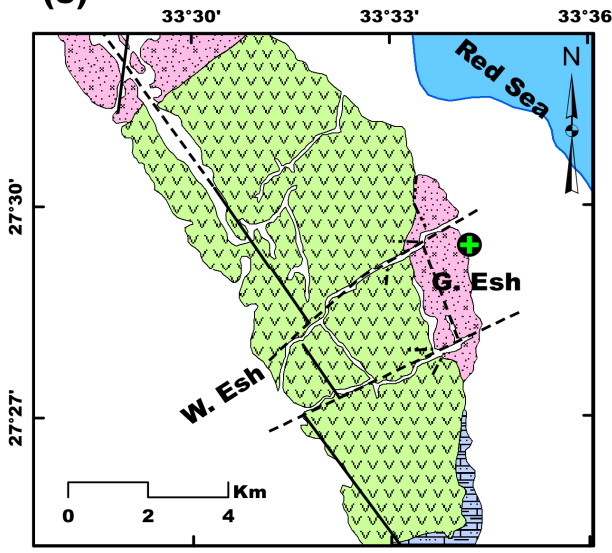

(b)
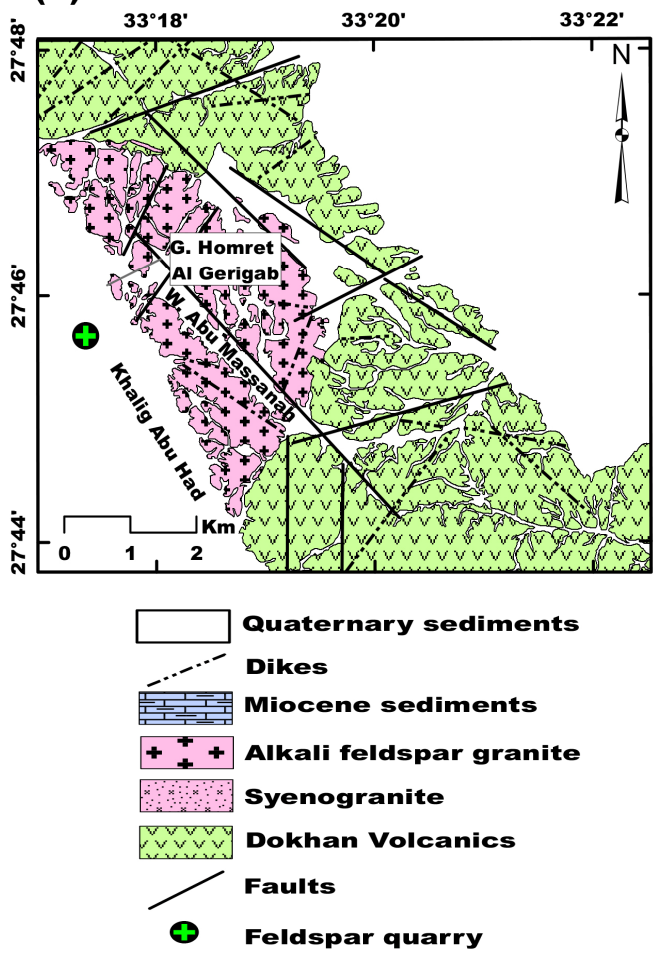

Fig. 1: (a) Regional map of the Egyptian Eastern Desert basement complex showing the locations of the study areas. Simplified geological maps of (b) Gabal Homret Al Gerigab area (After Abdel Hadi, 2013), (c) Gabal Esh area (After Azzaz, 2015)

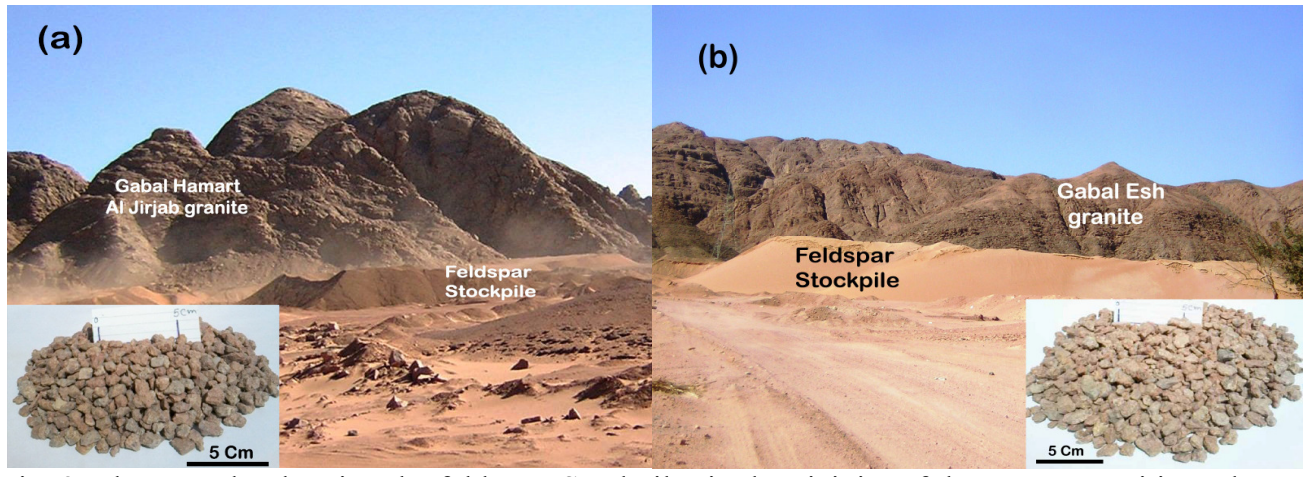

Fig. 2: Photographs showing the feldspar Stockpiles in the vicinity of the source granitic rocks at (a) Gabal Homret Al Gerigab and (b) Gabal Esh areas. 
collected from stockpiles including 20 samples from Gabal Homret Al Gerigab and 15 samples from Gabal Esh area. The collected feldspar samples of sizes between $1.0-0.5 \mathrm{Cm}$ were firstly crushed to about $0.250 \mathrm{~mm}$ (60 mesh) for radiometrical measurements then grinded to be powder and sieved between 0.250 and $0.074 \mathrm{~mm}$ for mineralogical study.

\section{Gamma-Ray Spectrometry}

The radiometrical measurements of all samples were performed by gamma-ray spectrometry, using a high-purity germanium (NaI "T1") detector connected to a multichannel analyzer in the Nuclear Materials Authority, Cairo, Egypt. Plastic containers of cylindrical shape $(9.5 \mathrm{~cm}$ diameter and $3 \mathrm{~cm}$ height) were filled with crushed samples (about 60 mesh) then sealed well and left for at least 30 days to accumulate free radon and attain radioactive equilibrium before counting. The measurements involve determining the equivalent of $\mathrm{U}, \mathrm{Th}, \mathrm{Ra}(\mathrm{ppm})$ and $\mathrm{K}(\%)$ concentrations using a high efficiency multichannel analyzer of gamma-ray spectrometer (NaI "T1" detector). The measurements are based on choosing four energy peaks, representing $\left(\mathrm{Th}^{234}: 92.6 \mathrm{Kev}\right)$, $\left(\mathrm{Pb}^{212}\right.$ : $\left.238.6 \mathrm{Kev}\right),\left(\mathrm{Pb}^{214}: 352 \mathrm{Kev}\right)$ and $\left(\mathrm{K}^{40}\right.$ : $1460.8 \mathrm{Kev}$ ) isotopes for $\mathrm{U}, \mathrm{Th}, \mathrm{Ra}$ and $\mathrm{K}$, respectively.

\section{Heavy Minerals Separation}

Selected 10 samples from the studied feldspars ( 5 from each area) were chosen on the basis of their radioactivity level for heavy minerals separation. The heavy fraction is separated by bromoform (sp.Gr. 2.89), followed by removal of magnetite by hand magnet. The obtained fractions were carefully studied using a Binocular Stereomicroscope. Semi-quantitative (EDX) analyses were carried out using a Phillips XL 30 Scanning Electron Microscope (SEM) in the NMA Lab.

\section{Calculation of Radiation Hazard Indices}

In order to assess the radiological impact of the studied feldspars as raw materials for ceramic industries, radiological parameters such as radium equivalent activity $\left(\mathrm{Ra}_{\mathrm{eq}}\right)$, external hazard index $\left(\mathrm{H}_{\mathrm{ex}}\right)$ and total air absorbed dose rate $\left(D_{R}\right)$ were calculated.

Radium equivalent activity can be calculated from the following relation suggested by Beretka and Mathew (1985):

$$
\mathrm{Ra}_{\mathrm{eq}}=\left(\mathrm{A}_{\mathrm{Th}} \times 1.43\right)+\mathrm{A}_{\mathrm{Ra}}+\left(\mathrm{A}_{\mathrm{K}} \times 0.077\right) \quad(\mathrm{Bq} / \mathrm{kg})
$$

External hazard index $\left(\mathrm{H}_{\mathrm{ex}}\right)$ due to the emitted gamma-rays of the samples are calculated and examined according to the following criterion (Beretka and Mathew, Op. Cit):

$$
\mathrm{H}_{\mathrm{ex}}=\left(\mathrm{A}_{\mathrm{Ra}} / 370\right)+\left(\mathrm{A}_{\mathrm{Th}} / 259\right)+\left(\mathrm{A}_{\mathrm{K}} / 4810\right) \quad(\mathrm{mGy} / \mathrm{yr})
$$

The total air absorbed dose rate $\left(\mathrm{D}_{\mathrm{R}}\right)$ due to the activity concentrations of ${ }^{238} \mathrm{U},{ }^{232} \mathrm{Th}$ and ${ }^{40} \mathrm{~K}(\mathrm{~Bq} / \mathrm{kg})$ can be calculated using the formula of UNSCEAR (1988):

$$
\mathrm{D}_{\mathrm{R}}=0.462 \mathrm{~A}_{\mathrm{Ra}}+0.604 \mathrm{~A}_{\mathrm{Th}}+0.042 \mathrm{~A}_{\mathrm{K}} \quad(\mathrm{nGy} / \mathrm{hr})
$$

Where, $A_{T h}, A_{R a}$ and $A_{K}$ are the activity concentrations of ${ }^{232} \mathrm{Th},{ }^{226} \mathrm{Ra}$ and ${ }^{40} \mathrm{~K}$, respectively in $(\mathrm{Bq} / \mathrm{kg}) .1 \mathrm{~Bq}^{238} \mathrm{U} /$ $\mathrm{kg}=12.35 \times \mathrm{U}(\mathrm{ppm}) ; 1 \mathrm{~Bq}^{232} \mathrm{Th} / \mathrm{kg}=4.06 \times \mathrm{Th}(\mathrm{ppm}) ; 1 \mathrm{~Bq}^{226} \mathrm{Ra} /$ $\mathrm{kg}=12.35 \times \mathrm{Ra}(\mathrm{ppm})$ and $1 \mathrm{~Bq}{ }^{40} \mathrm{~K} / \mathrm{kg}=313 \times \mathrm{K}(\%)$.

\section{RESULTS AND DISCUSSIONS}

\section{Radioactivity Measurements}

The radiometric investigations of the Egyptian granites highlighted their relatively higher concentrations of natural radionuclides $\left({ }^{238} \mathrm{U},{ }^{232} \mathrm{Th},{ }^{226} \mathrm{Ra}\right.$, and $\left.{ }^{40} \mathrm{~K}\right)$ than the other rock types (El Arabi et al. 2000; Ahmed et al. 2006; Harb et al. 2012). However, the stream sediments originated from these rocks are usually reflected their radionuclides concentrations even in some cases are higher than the background of the source granitic rocks.

The results of the laboratory radiometric analyses including concentrations of equivalent $\mathrm{U}$, Th, $\mathrm{Ra}(\mathrm{ppm})$, and $\mathrm{K}(\%)$ radionuclides as well as the calculated $\mathrm{eTh} / \mathrm{eU}$ ratios and radiological hazard parameters for the studied feldspars are listed in Table (1).

The averages of eU concentrations are 15.6 and 7.5 ppm for Homret Al Gerigab and Gabal Esh areas, respectively, while for eTh contents are 30.7 and 18.9ppm (Table 1). The 
mean value of $\mathrm{Ra}$ is $7.7 \mathrm{ppm}$ in Homret $\mathrm{Al}$ Gerigab samples, which is nearly twice the average $4.7 \mathrm{ppm}$ for Gabal Esh samples (Table 1). Overall, the K (\%) contents of the studied samples are generally high in accordance with their derivation from granitic composition rich in $\mathrm{k}$-feldspar. The average values of $\mathrm{K}$ concentrations are 3.61\% in Gabal Homret Al Gerigab area and 3.71\% in Gabal Esh samples (Table 1). It is clear that the radionuclide concentrations of all feldspar samples are higher than the permissible levels 2.8, 11.1, 2.7 (ppm) and $1.34 \%$ (Table 1 ) for $\mathrm{U}, \mathrm{Th}, \mathrm{Ra}$ and $\mathrm{K}$, respectively (UNSCEAR, 2000).

The averages of eTh/eU ratios are 2.0 and 2.5 for Homret Al Gerigab and Gabal Esh areas respectively, which are lower than that reported in the literature (3-4.5) for the source granitic rocks (Faüre, 1986; Kabata-Pendias and Pendias, 1992), mainly due to the high U concentrations.

A comparison between the average activity concentrations of the studied feldspar samples among the two study areas indicates that the natural radionuclides of Gabal Homret $\mathrm{Al}$ Gerigab are higher than those in Gabal Esh area (Fig. 3).

\section{Accessory Mineral Concentrations and Characteristics}

The composition and abundance of the accessory minerals in the investigated feldspars will be evaluated as they act as the source of $U$ and Th. The evaluation is achieved by calculating the weight percentages of each mineral through grain counting and semi-quantitative

Table 1: Activity concentrations of $\mathrm{U}, \mathrm{Th}, \mathrm{Ra}$ and $\mathrm{K}$ with calculated $\mathrm{Th} / \mathrm{U}$ ratios and radiological hazard parameters of the studied feldspars

\begin{tabular}{|c|c|c|c|c|c|c|c|c|c|c|}
\hline \multirow{2}{*}{$\begin{array}{l}\text { Study } \\
\text { area }\end{array}$} & \multirow[b]{2}{*}{$\begin{array}{r}\text { Serial } \\
\text { No. }\end{array}$} & \multirow[b]{2}{*}{$\begin{array}{r}\text { Sample } \\
\text { No. }\end{array}$} & \multicolumn{4}{|c|}{ Activity concentrations } & \multirow[b]{2}{*}{$\mathbf{e T h} / \mathbf{e U}$} & \multirow[b]{2}{*}{$\begin{array}{r}\mathbf{R a}_{\mathbf{e q}} \\
(\mathbf{B q} / \mathbf{k g})\end{array}$} & \multirow[b]{2}{*}{$\begin{array}{r}H_{e x} \\
(m G y / y r)\end{array}$} & \multirow[b]{2}{*}{$\begin{array}{r}D_{\mathrm{R}} \\
(\mathrm{nGy} / \mathrm{hr}\end{array}$} \\
\hline & & & $\begin{array}{r}\mathbf{e U} \\
(\mathbf{p p m})\end{array}$ & $\begin{array}{r}\text { eTh } \\
\text { (ppm }\end{array}$ & $\begin{array}{c}\mathbf{R a} \\
\text { (ppm) }\end{array}$ & $\begin{array}{r}\mathbf{K} \\
(\%) \\
\end{array}$ & & & & \\
\hline & 1 & HJ-1 & 12 & 23 & 6 & 3.51 & 1.9 & 292.2 & 0.8 & 136.8 \\
\hline & 2 & HJ-2 & 17 & 38 & 10 & 2.66 & 2.2 & 408.2 & 1.1 & 185.2 \\
\hline & 3 & HJ-3 & 15 & 25 & 5 & 3.23 & 1.7 & 284.7 & 0.8 & 132.3 \\
\hline & 4 & HJ-4 & 11 & 18 & 4 & 3.08 & 1.6 & 228.1 & 0.6 & 107.5 \\
\hline & 5 & HJ-5 & 15 & 35 & 8 & 3.94 & 2.3 & 397.0 & 1.1 & 183.3 \\
\hline & 6 & HJ-6 & 21 & 32 & 12 & 4.04 & 1.5 & 431.4 & 1.2 & 200.0 \\
\hline & 7 & HJ-7 & 14 & 37 & 7 & 3.42 & 2.6 & 383.7 & 1.0 & 175.6 \\
\hline & 8 & HJ-8 & 17 & 30 & 8 & 3.89 & 1.8 & 366.7 & 1.0 & 170.4 \\
\hline & 9 & HJ-9 & 11 & 26 & 6 & 3.47 & 2.4 & 308.7 & 0.8 & 143.6 \\
\hline Gabal & 10 & HJ-10 & 15 & 36 & 6 & 3.22 & 2.4 & 360.7 & 1.0 & 164.8 \\
\hline Homret & 11 & HJ-11 & 13 & 31 & 7 & 2.51 & 2.4 & 326.9 & 0.9 & 149.0 \\
\hline Al & 12 & HJ-12 & 24 & 49 & 10 & 3.25 & 2.0 & 486.3 & 1.3 & 219.9 \\
\hline \multirow[t]{16}{*}{ Gerigab } & 13 & HJ-13 & 22 & 41 & 15 & 3.62 & 1.9 & 510.5 & 1.4 & 233.7 \\
\hline & 14 & HJ-14 & 13 & 22 & 6 & 3.28 & 1.7 & 280.9 & 0.8 & 131.3 \\
\hline & 15 & HJ-15 & 12 & 20 & 5 & 4.57 & 1.7 & 288.0 & 0.8 & 137.7 \\
\hline & 16 & HJ-16 & 16 & 32 & 7 & 3.47 & 2.0 & 355.9 & 1.0 & 164.0 \\
\hline & 17 & HJ-17 & 24 & 45 & 11 & 3.68 & 1.9 & 485.8 & 1.3 & 221.5 \\
\hline & 18 & $\mathbf{H j - 1 8}$ & 16 & 34 & 9 & 4.93 & 2.1 & 427.4 & 1.2 & 199.5 \\
\hline & 19 & Hj-19 & 14 & 21 & 5 & 4.76 & 1.5 & 298.4 & 0.8 & 142.6 \\
\hline & 20 & $\mathbf{H j} \mathbf{j}-20$ & 10 & 19 & 6 & 3.61 & 1.9 & 271.4 & 0.7 & 128.3 \\
\hline & Av. & & 15.6 & 30.7 & 7.7 & 3.61 & 2.0 & 359.6 & 1.0 & 166.3 \\
\hline & 21 & $\overline{E-1}$ & 8 & 20 & 5 & 4.85 & 2.5 & 294.8 & 0.8 & 141.3 \\
\hline & 22 & E-2 & 7 & 16 & 4 & 4.39 & 2.3 & 248.1 & 0.7 & 119.8 \\
\hline & 23 & E-3 & 4 & 12 & 4 & 1.83 & 3.0 & 163.2 & 0.4 & 76.30 \\
\hline & 24 & E-4 & 8 & 25 & 5 & 3.48 & 3.1 & 290.8 & 0.8 & 135.6 \\
\hline & 25 & E-5 & 7 & 17 & 4 & 1.69 & 2.4 & 188.8 & 0.5 & 86.73 \\
\hline & 26 & E-6 & 9 & 27 & 5 & 2.28 & 3.0 & 273.5 & 0.7 & 124.7 \\
\hline & 27 & E-7 & 5 & 14 & 5 & 2.46 & 2.8 & 202.3 & 0.5 & 95.20 \\
\hline \multirow{9}{*}{$\begin{array}{l}\text { Gabal } \\
\text { Esh }\end{array}$} & 28 & E-8 & 8 & 18 & 4 & 4.82 & 2.3 & 270.1 & 0.7 & 130.3 \\
\hline & 29 & E-9 & 6 & 10 & 3 & 3.49 & 1.7 & 179.2 & 0.5 & 87.52 \\
\hline & 30 & E-10 & 9 & 29 & 6 & 4.57 & 3.2 & 352.6 & 1.0 & 165.4 \\
\hline & 31 & E-11 & 6 & 18 & 5 & 3.65 & 3.0 & 254.2 & 0.7 & 120.7 \\
\hline & 32 & E-12 & 12 & 28 & 7 & 3.31 & 2.3 & 328.8 & 0.9 & 152.1 \\
\hline & 33 & E-13 & 9 & 12 & 3 & 3.52 & 1.3 & 191.6 & 0.5 & 92.82 \\
\hline & 34 & E-14 & 10 & 24 & 6 & 5.44 & 2.4 & 344.5 & 0.9 & 164.6 \\
\hline & 35 & E-15 & 5 & 13 & 4 & 3.64 & 2.6 & 212.6 & 0.6 & 102.6 \\
\hline & Av. & & 7.5 & 18.9 & 4.7 & 3.71 & 2.5 & 253.0 & 0.7 & 119.7 \\
\hline \multicolumn{3}{|c|}{ World average (UNSCEAR, 2000) } & 2.8 & 11.1 & 2.7 & 1.3 & & 370 & 1.0 & 58 \\
\hline
\end{tabular}




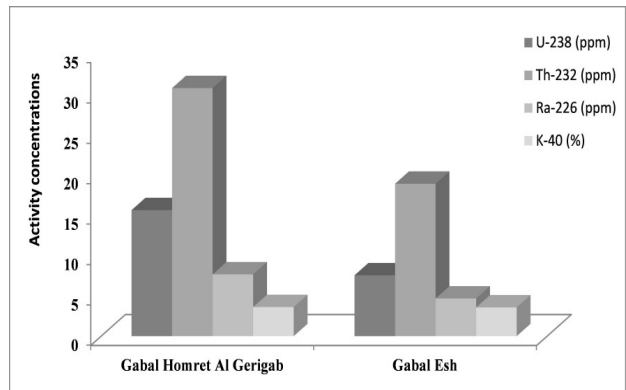

Fig.3: Comparison between the average concentrations of eU, eTh, Ra (ppm) and $\mathrm{K}(\%)$ of the feldspars among the two study areas

(EDX) analysis of the common accessory phases. The accessory minerals consist mainly of magnetite, ilmenite, hematite, sphene, rutile, zircon, monazite, fluorite and apatite as well as garnet and epidote.

To obtain a grain count of the common accessory minerals, the heavy fraction free of magnetite was split several times to obtain adequate quantity suitable for counting (about 700 grains) under the Binuclear Stereomicroscope. The weight percentage of each mineral relative to the corresponding original sample was calculated according to Kellagher and Flanagan (1955) equation and given in Table (2).

$$
\mathrm{Q}=\mathrm{P} \cdot \mathrm{n}_{\mathrm{m}} \cdot \mathrm{d}_{\mathrm{m}} / \sum\left(\mathrm{n}_{\mathrm{o}} \cdot \mathrm{d}_{\mathrm{o}}\right)
$$

Where, Q: the weight percentages of the concerned mineral, P: the weight percentages of the corresponding magnetic fraction, $\mathrm{n}_{\mathrm{m}}$ : the number of grains of the mineral, $\mathrm{d}_{\mathrm{m}}$ : specific gravity of the mineral and $\sum\left(\mathrm{n}_{0} \cdot \mathrm{d}_{\mathrm{o}}\right)$ : the sum of the number of grains for each mineral multiplied by its specific gravity.

Magnetite and ilmenite are essential minerals in the studied feldspars, with averages of 0.633 and 0.053 wt. \%, respectively in Homret $\mathrm{Al}$ Gerigab samples and 0.715 and $0.050 \mathrm{wt}$. $\%$ in Gabal Esh dataset (Table 2). Magnetite is found as homogenous angular to slightly rounded grains. Heterogeneous magnetite grains are also present with hematite intergrowths. On the other hand,ilmenite occurs as tabular or angular to subrounded grains.
Table 2: The accessory minerals contents(wt. \%) of the investigated feldspars

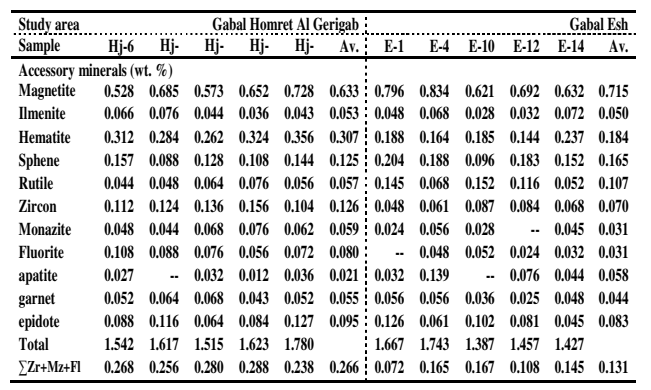

Sphene is mainly present as anhedral, irregular, angular to subrounded and less commonly tabular crystals (Fig. 4). The concentrations in Homret Al Gerigab data set have an average 0.125 wt. \%, whereas in Gabal Esh samples the average value is higher 0.165 wt. \% (Table 2). The BSE image and EDX spectrum of representative sphene grains are shown on Figure (5). Its major constituents are $\mathrm{Ti}, \mathrm{Ca}$ and $\mathrm{Si}$ with minor amounts of $\mathrm{Na}$, $\mathrm{Al}$, and $\mathrm{Fe}$.

Hematite is present through the alteration of magnetite and/or sulphides.Its high contents are noticed in Homret Al Gerigab area, with an average 0.307 wt. \%, and lower in Gabal Esh

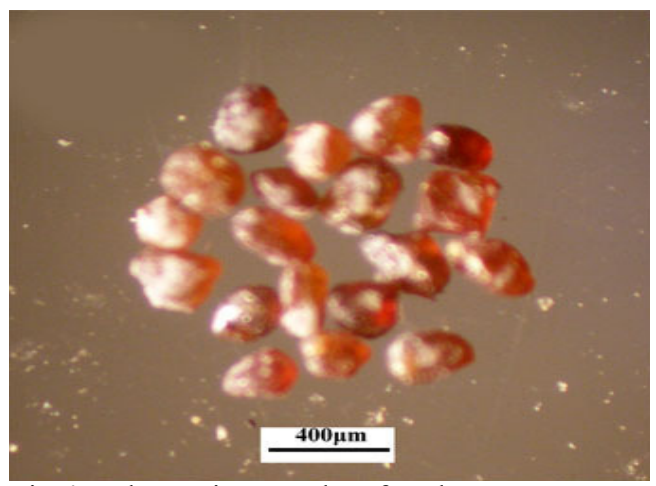

Fig.4: Photomicrograph of sphene accessory mineral grain separated from feldspars of the two study areas 


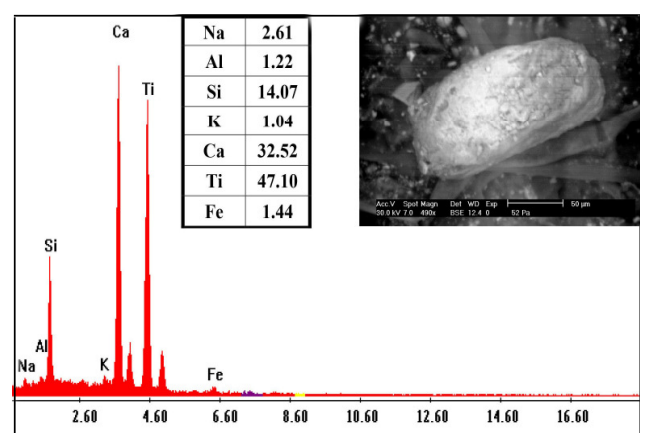

Fig.5: ESEM image and EDX analysis of sphene

samples with an average $0.184 \mathrm{wt} . \%$ (Table 2). It exists as anhedral to subhedral grains with reddish brown or dark red color and metallic or dull luster. ESEM and EDX analysis showing that hematite staining the feldspar grains in some samples (Fig. 6). Rutile is subhedral prismatic, tabular and elongated crystals with adamintine luster (Fig.7). It is present in all samples with average values $0.057 \mathrm{wt} . \%$ in Homret Al Gerigab area and 0.107 wt. $\%$ in Gabal Esh area (Table 2). The SEM microphotographs and EDX analysis of representative rutile grains reveal that they mainly consist of Ti with minor amounts of $\mathrm{Al}, \mathrm{Si}$ and $\mathrm{Ca}$ (Fig. 8).

Zircon is the most common U-Th bearing

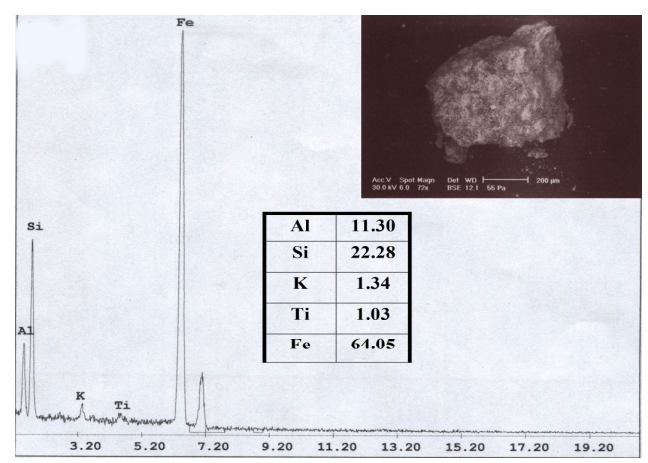

Fig.6: ESEM image and EDX analysis of Hematite staining feldspars

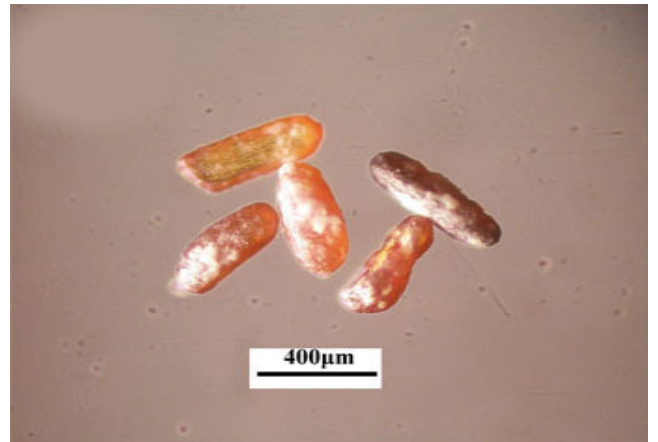

Fig.7: Photomicrograph of rutile accessory mineral grain separated from feldspars of the two study areas

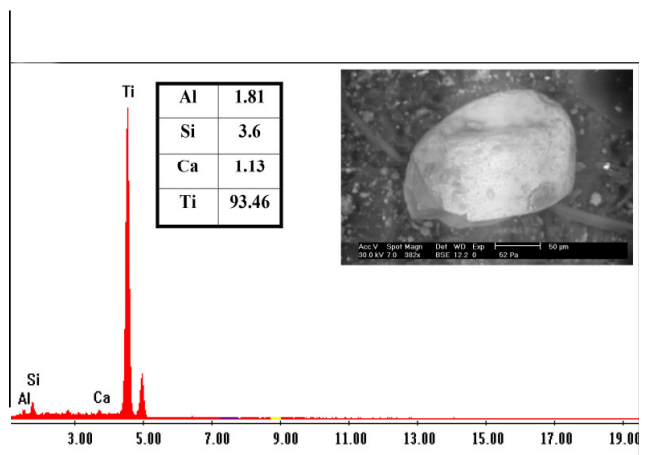

Fig.8:ESEM image and EDX analysis of rutile

mineral in all studied samples. The higher frequencies are observed in Homret Al Gerigab samples (av. $=0.126$ wt. \%) and decrease in Gabal Esh area with an average of 0.070 wt. $\%$ (Table 2). Most of zircon occurs as short prismatic to long prismatic crystals with bipyramidal form (Fig. 9). The EDX data of representative zircon grains from the study areas mostly show the presence of notable concentrations of $\mathrm{U}(0-3.26$ wt. \%) and Th (0.19-2.47 wt. \%), in its chemical formula.These radioelements cause the metamictization of the grains due to the alpha bombardment during the decay process of $U$ and Th (Fig. 10). On the other hand, some grains have inclusions of radioactive materials. The EDX analysis reveals the presence of uranothorite (Fig. 11). 


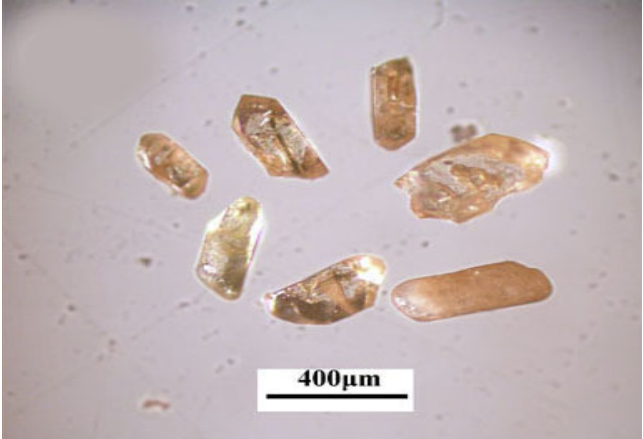

Fig.9: Photomicrograph of the separated zircon from the two study areas

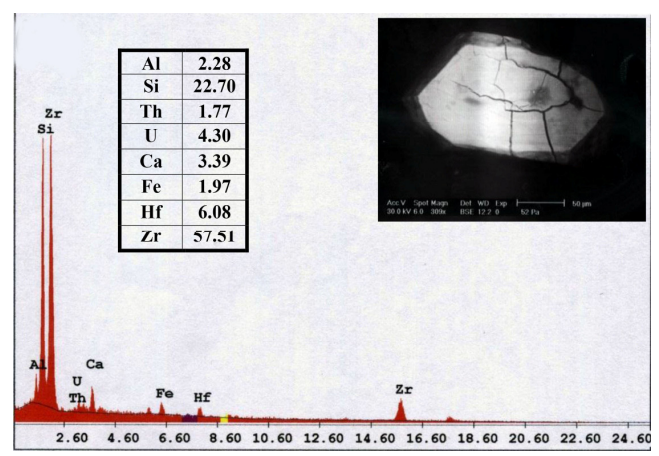

Fig.10: ESEM image and EDX analysis of metamictized zircon

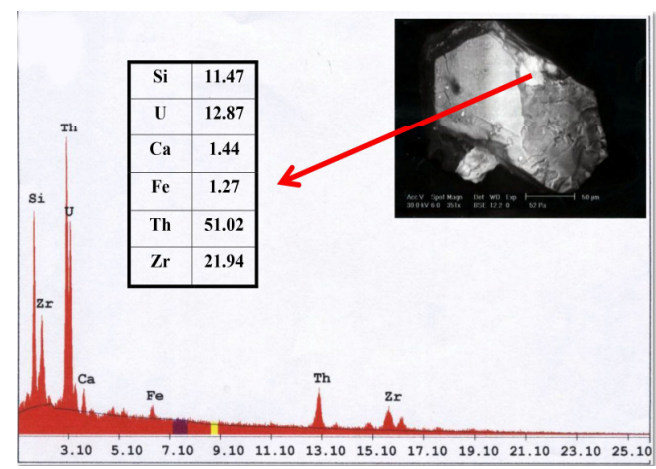

Fig.11: ESEM image and EDX analysis of zircon with uranothorite inclusions
Monazite is one of the most important radioactive mineral; being a major host for REE, Th and U (Hurley and Fairbairn, 1957). Monazite has low concentrations compared to zircon among the studied samples but its concentrations are higher in Homret Al Gerigab samples (av. $=0.059$ wt. \%) than Gabal Esh dataset (av. $=0.031$ wt. \%; Table 2). It displays habits varying from anhedral to subhedral and sometimes rounded with honey to yellowish, reddish brown and brown colors and resinous luster (Fig. 12). The semi-quantitative analysis (EDX) of the studied monazite shows that $\mathrm{Ce}$ is the dominant cation and so this monazite can be referred as (Ce )-monazite. It has notable concentrations of $\mathrm{U}$ and $\mathrm{Th}$ with averages of 2.21 and 9.51 wt. \%, respectively (Fig. 13).

Fluorite is found as anhedral, angular to subangular grains with irregular outlines and sharp edges and has vitreous luster (Fig. 14). Fluorite exhibits high frequency (av. $=0.080$ wt. \%) in Homret Al Gerigab samples than Gabal Esh samples (av. $=0.031$ wt. \%; Table 2 ). It shows a wide range of colors from rose, violet to deep violet and colorless crystals are also observed. Such changes in color are attributed to emanations from (or inclusions of) nearby radioactive material, traces of REE or others (Deer et al., 1992) or to the presence of $\mathrm{Y}$ in particular (Fayziyev, 1990). The semiquantitative analysis of violet to deep violet

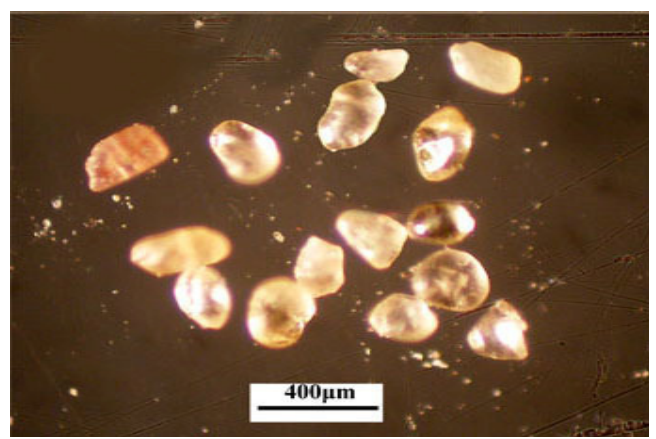

Fig.12: Photomicrograph of the separated monazite of the two study areas 


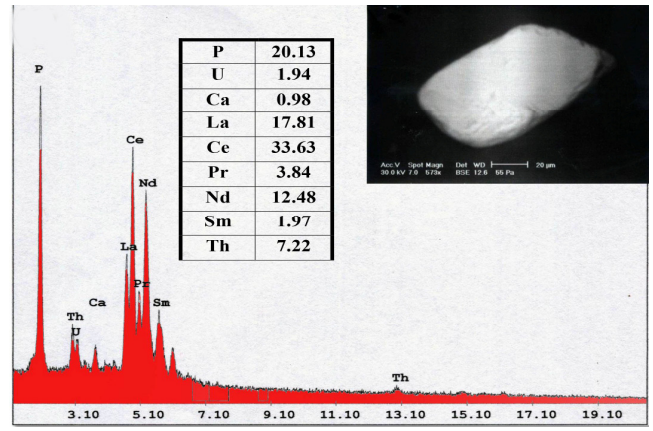

Fig.13: ESEM image and EDX analysis of monazite

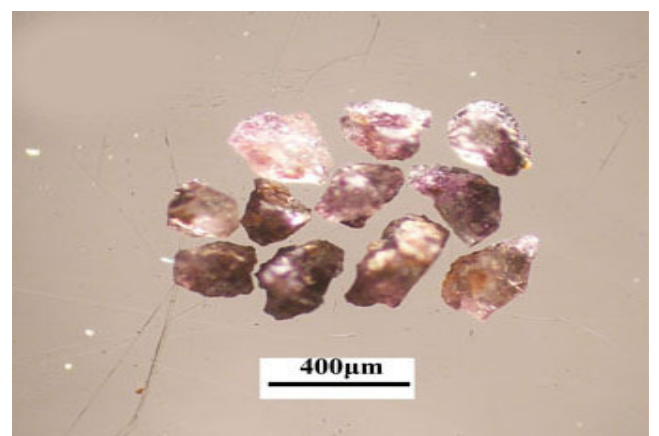

Fig.14: Photomicrograph of the separated fluorite from the two study areas

fluorite confirms the presence of $\mathrm{Y}$ in the mineral compositions (Fig. 15), while some grains show inclusions of radioactive materials such as kasolite (Fig.16).

Apatite is low in all studied samples; its concentrations have an average of $0.021 \mathrm{wt}$ \% in Homret $\mathrm{Al}$ Gerigab samples and increased to 0.058 wt. \% in Gabal Esh samples (Table $2)$. It occurs as colorless subhedral to euhedral grains of good vitreous luster (Fig. 17). The ESEM image and EDX analysis of apatite indicates that its composition is pure $\mathrm{CaO}$ and $\mathrm{P}_{2} \mathrm{O}_{5}$ (Fig. 18).

Garnet of almandine type and epidote are present in the studied feldspar deposits in

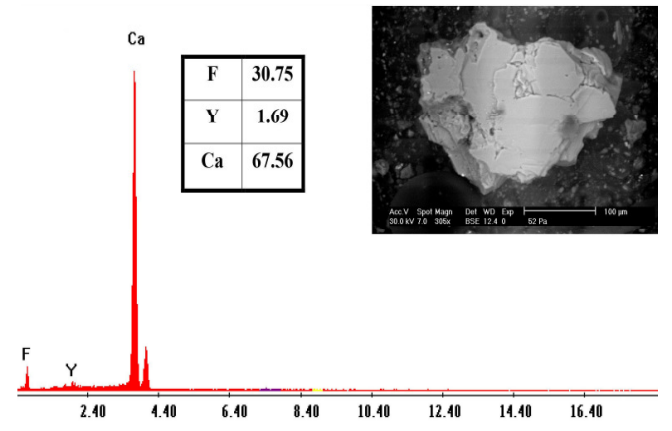

Fig.15: ESEM image and EDX analysis of colorless fluorite

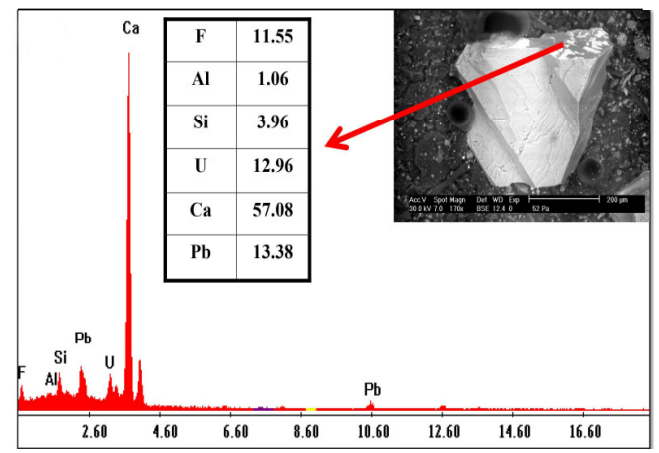

Fig.16:ESEM image and EDX analysis of deep violet fluorite with kasolite inclusion

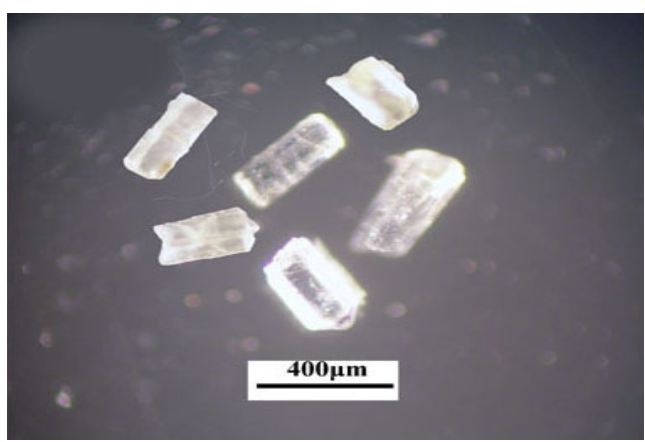

Fig.17: Photomicrograph of the separated apatite from the two study areas 


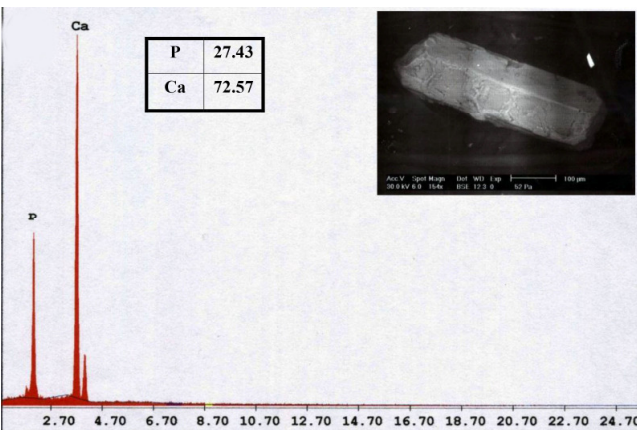

Fig.18: ESEM image and EDX analysis of apatite

various proportions. The average contents of garnet and epidote are 0.055 and 0.095 wt. $\%$, respectively in Homret Al Gerigab area whereas in Gabal Esh area their frequancies have average of 0.044 and 0.083 wt. \% (Table 2). ESEM image and EDX spectrum of garnet are showing on Figure (19).

From the previous results, it is concluded that zircon, monazite and to a lesser extent fluorite are the main U-Th bearing minerals, which dominantly have these radioanuclides in their lattice structure or inclusions of radioactive materials. The presence or absence of these radioactive minerals in the concerned feldspars contributes directly to the level of

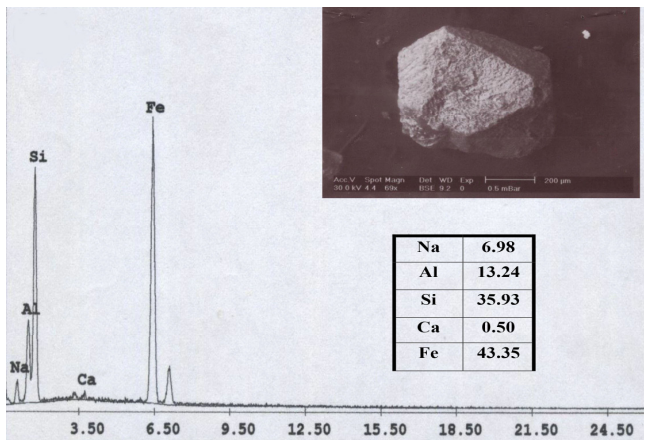

Fig.19: ESEM image and EDX analysis of garnet the radioactivity of the investigated sample. From Table (2), the sum of zircon, monazite and fluorite, among the studied samples, are higher in Homret Al Gerigab area (av. $=0.266$ wt. \%) than in Gabl Esh area (0.131 wt. \%). This indicated that the higher measurements of natural radionuclides in Gabal Homret Al Gerigab are the result of higher quantities of radioactive minerals.

\section{Evaluation of The Radiological Hazards}

The radium equivalent activity $\left(\mathrm{Ra}_{\mathrm{eq}}\right)$ is calculated by the formula Eq. (1) and listed in Table (1). The mean values of radium equivalent activities for the feldspar samples of Homret Al Gerigab and Gabal Esh areas are 359.6 and $253 \mathrm{~Bq} / \mathrm{kg}$, respectively (Table 1), which are below the maximum recommended value $370 \mathrm{~Bq} / \mathrm{kg}$ (Berteka and Mathew, 1985). It is worth to mention that seven feldspar samples from Homret Al Gerigab area showing radium equivalent activities higher than the recommended value (Table 1).

The external hazard index $\left(\mathrm{H}_{\mathrm{ex}}\right)$ can be calculated from the Eq. (2) (Berteka and Mathew, 1985). The results of $\mathrm{H}_{\mathrm{ex}}$ based on the criterion formula Eq. (2) are given in Table (1). The average values are 1.0 and 0.7 (mGy/ yr) for Homret Al Gerigab and Gabal Esh feldspar samples, respectively; the recommended value is less than unity (UNSCEAR, 2000). In Homret Al Gerigab area, seven feldspar samples have $\mathrm{H}_{\mathrm{ex}}$ values greater than one (Table 1).

The absorbed dose rate is calculated by the formula Eq. (3) and given in Table (1). The average absorbed dose rates for Homret Al Gerigab and Gabal Esh feldspar samples are 166.3 and $119.7 \mathrm{nG} / \mathrm{hr}$, respectively. According to UNSCEAR (2000) the corresponding worldwide average value is $58 \mathrm{nG} / \mathrm{hr}$. This reveals that the mean absorbed dose rates in air outdoors from the studied feldspar samples are higher than three and two times that of worldwide average value.

On the basis of the previous results, especially the dose rate values, it appears that 
irradiation is higher and may causing risk to human health when using in building materials. The radiation exposure and attributed risk of the studied feldspars should be reduced and intensive purification from the radionuclides is necessary during the manufacture of ceramics.

\section{CONCLUSIONS}

The investigated feldspars are separated from the stream sediments of both Gabal Homret Al Gerigab and Gabal Esh areas located in Esh El Melaha range. The activity concentrations of $\mathrm{U}, \mathrm{Th}, \mathrm{Ra}$ and $\mathrm{K}$ in feldspar samples in the present study have been measured using gamma- spectrometry system. The maximum concentrations of $\mathrm{U}, \mathrm{Th}$ and $\mathrm{Ra}$ are recorded in Gabal Homret Al Gerigab feldspars, while $\mathrm{K}$ contents are higher in all feldspar samples. The activities of the studied feldspar samples are higher than the recommended levels 2.8 , $11.1,2.7$ (ppm) and $1.3(\%)$, of U, Th, Ra and $\mathrm{K}$, respectively reported by UNSCEAR (2000).

The mineralogical studies of the investigated feldspars indicated that they contain common accessory minerals of magnetite, ilmenite hematite, rutile, sphene, zircon, monazite, fluorite and apatite besides garnet and epidote. Among these minerals, zircon, monazite and to a lesser extent fluorite are the main U-Th-bearing minerals and their quantities in the sample could justify the level of natural radioactivity. The higher contents of these minerals in Gabal Hamrat Al Jirjab samples cause increasingin their radioactivity compared to Gabal Esh area.

The mean values of radium equivalent activity are $359.6 \mathrm{~Bq} / \mathrm{kg}$ and $166.3 \mathrm{~Bq} / \mathrm{kg}$ for Homret Al Gerigab and Gabal Esh areas, respectively which are below the recommended value of $370 \mathrm{~Bq} / \mathrm{kg}$. The averages of external hazard index are 1.0 and $0.7 \mathrm{mGy} / \mathrm{yr}$, respectively which are equal and below the safe limit. For absorbed dose rate the averages are 166.3 and $119.7 \mathrm{nG} / \mathrm{hr}$, respectively higher three and two times the recommended value $58 \mathrm{nG} / \mathrm{hr}$. The elevated values of absorbed dose rat may cause a great effect on the health of humans when used in ceramic industry. We recommended that radiation exposure should be reduced by specific technologies of magnetic separation and chemical processing to reduce the concentrations of the radionuclides from the feldspars during manufacture of ceramics.

\section{Acknowledgements}

The authors express their thanks to Prof. M. H. Shalaby, Nuclear Materials Authority, for his numerous helpful discussions. Thanks are also due to Prof. H. M. Abdallah, and Prof. M. F. Raslan, Nuclear Materials Authority, for their critical reviews and suggestions, which have substantial improved the manuscript.

\section{REFERENCES}

Abdel Hadi, A.M., 2013. Mineralogical and geochemical prospection and radioelements distribution in Hamrat Al Jirjab stream sediments, Esh El Melaha range, North Eastern Desert, Egypt. Ph.D Thesis, Benha Univ., Fac. Sci., $251 \mathrm{p}$.

Aboelkhair, H.; Ibrahim, T., and Saad, A., 2012. Gamma activity of stream sediment feldspars as ceramic raw materials and their environmental impact. Radiation Protection Dosimetry, 151(1), 175-182.

Ahmed, N.K.; Abbady, A.; El-Arabi, A.M.; Michel, R.; El-Kamel, A.H., and Abbady, E.G.A., 2006. Comparative study of the natural radioactivity of some selected rocks from Egypt and Germany. Indian J. Pure and Applied Physics, 44, 209-215.

Azzaz, S.A.; Blasy, M.; Moharem, A., and Amer, O., 2015. Late Neoproterozoic Dokhan volcanics, around G. Esh, North Eastern Desert, Egypt: geochemistry and relation of $\mathrm{K}_{2} \mathrm{O}$ and $\mathrm{Nb}$ abundances with crustal thickness. Arabian J. Geoscience., 8 (6), 3551-3564.

Beretka, J., and Mathew, P.J., 1985. Natural radio- 
activity of Australian building materials, industrial wastes and by-products. Health Phys., 48, 87-95.

Deer, W.A.; Howie, R.A., and Zussman, J., 1992. An introduction to the rock forming minerals ( $2^{\text {nd }}$ Edition). Longman Scientific \& technical, 696p.

El-Arabi, A.M.; Ahmed, N.K., and El-Kamel, A.H., 2000. Gamma spectroscopic analysis of powdered granite samples in some eastern desert's areas. Proc. $5^{\text {th }}$ Radiation Conf., Cairo, Egypt.

Esmail, E. M., and Tawfik S. Z., 2015. Geochemistry and uranium-thorium distributions in the younger granites of Esh El-Mallaha Range, North Eastern Desert, Egypt. Inter. J. Innovative Sci., Engineering \& Technology, 2 (12), 2348-7968.

Faüre, G., 1986. The U, Th-Pb methods of dating. In: Principles of isotope geology ( $2^{\text {nd }}$ Edition $)$. John Wiley \& Sons, 228- 308.

Fayziyev, A.R., 1990 .Yttrium in fluorite from endogenous shows in USSR. Translated from Geokhimiya, 7, 1037-1042.

Fullagar, P.D., and Greenberg, J. K., 1978. Egyptian younger granites: a single period of plutonism? . Precambrian Research, 6, A22-23.

Harb, S.; Abbady, A.; El-Kamel, A.; Saleh, I.I., and Abd El-Mageed, A.I., 2012. Natural radioactivity and their radiological effects for different types of rocks from Egypt. Radiation Physics and Chemistry, 81, 221-225.

Hashad, A.H., 1980. Present status of geochronological data on the Egyptian basement complex. Bull. Inst. Appl. Geol., King Abdul Aziz Univ., Jeddah, 3, 31-46.

Hurley, M.P., and Fairbairn, W.H., 1957. Abundance and distribution of uranium and thorium in zircon, sphene, apatite, epidote, and monazite in granitic rocks. Eos, Transactions American Geophysical Union, 38 (6), 939-944.

Kabata-Pendias, A., and Pendias, H., 1992. Trace elements in soils and plants. Boca Ratón, Florida7 CRC Press.

Kellagher, R.C., and Flanagan, P.J., 1955. A comparison of two methods for converting grain counts to weight percent composition. Internal report USGS-TEI-497, 15p.

Meneisy, M.Y., and lenz, H., 1982. Isotopic ages of some Egyptian granites. Ann. Geol. Surv. Egypt, XII, 7-14.

Moussa, E.M., 1998. Geochronological studies of some granitoids; application to geochemical evolution and tectonic history of the northern Eastern Desert, Egypt. Ph.D. Thesis, Fac. Sci., Ain Shams Univ., Egypt, 284p.

UNSCEAR, 1988. United Nations. Sources and Effects of Ionizing Radiation, Report to Ionizing Radiation: Sources and Biological Effects. And, Report to The General Assembly, With Scientific Annexes. United Nations Sales Publication E.94.Ix.2. United Nations, New York.

UNSCEAR, 2000. Report to General Assembly. Annex B: Exposure from Natural Radiation Sources. Report to General Assembly, With Scientific Annexes. Sources and Effects of Ionizing Radiation.United Nations Sales Publications No. E.00.Ix.3, I: Sources and No. E.00. Ix.4 ( Ii: Effects). United Nations, New York, 1220 p.

Walley El-Dine, N.; El-Shershaby, A.; Afifi, S.; Sroor, A., and Samir, E., 2011. Natural radioactivity and Rare Earth elements in feldspar samples, Central Eastern desert, Egypt. Applied Radiation and Isotopes, 69, 803-807. 


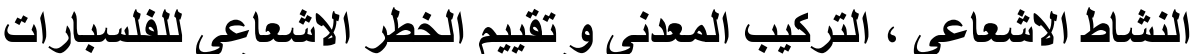

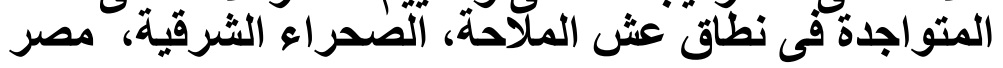

\author{
عمرو عبد العاطى عبد الحميد و حسن اسماعيل الصندولى

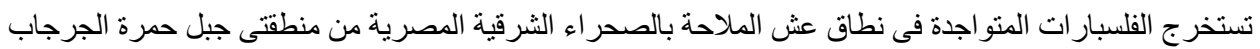

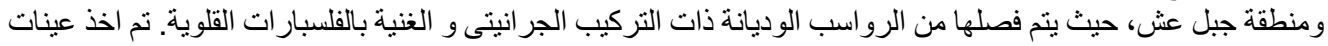

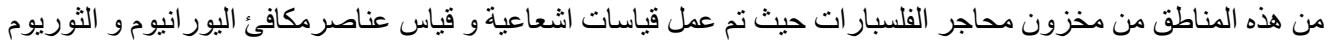

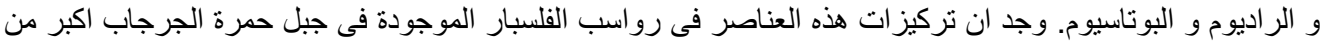

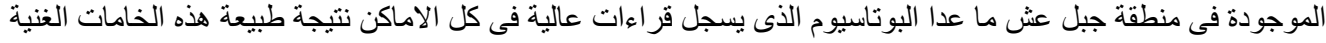 \\ اكدت الدراسات المعدنية ان معادن الزركون و المونازيت بالاضافة الى الفلوريت هم أكثر المعادن الحاملة \\ بالفلسبار القلوى.

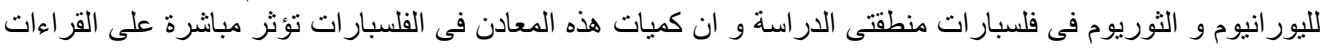

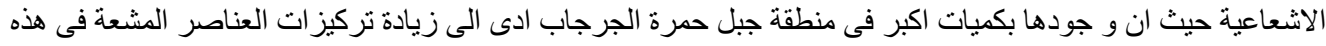

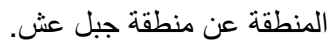

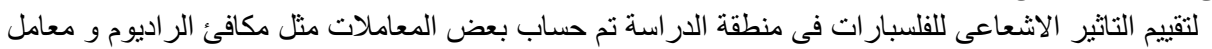

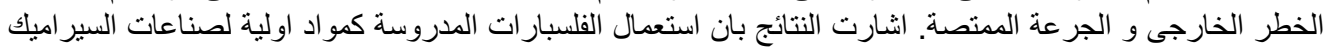

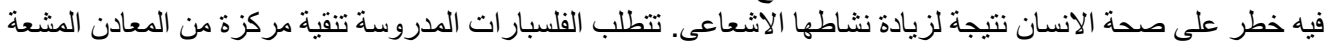 \\ بتطبيق التقنيات المناسبة من الفصل المغناطيسى و العمليات الكيميائية.
}

